\title{
Efforts to include geological and geodetic observations in the assessment of earthquake activity in Denmark
}

\author{
Søren Gregersen and Peter H. Voss
}

Assessment of earthquake hazard is improved if geological and geodetic data are included in addition to seismological data. In earthquake regions like Japan and California, palaeoseismology combines data from geology and seismology, and networks of permanent GPS (global positioning system) stations situated on bedrock supplement the networks of seismographs. A combination of seismographs and GPS stations on ice is also used in current studies of glacial earthquakes in Greenland. In Denmark only broad-scale geodetic coverage is available (Khan et al. 2005) and only a few examples of geological input are found in the literature. However, more thorough geodetic evaluations of deformations are currently made in Nordic co-operation projects and we are looking forward to learn about the results. Also the number of permanent GPS stations in Denmark has recently been increased from 3 to 13 . The geological input is limited but may hold some potential, and the aim of this article is to evaluate this. We also discuss new investigations of recent geological movements, both in projects on post-glacial uplift (and accompanying horizontal deformation) of Scandinavia, and more locally of geological indicators of uplift in selected areas. As seismologists, we are interested in a homogeneous evaluation of geological indicators in all of Denmark and its neighbouring areas.

In two recent seismological papers, we emphasised the very low earthquake activity in Denmark, even in the geologically significant Sorgenfrei-Tornquist Zone (Gregersen \& Voss 2009, 2010). The recorded earthquake activity over
Fig. 1. Map of North-West Europe showing the locations of earthquakes recorded from January 1970 to December 2004. Earthquakes in Denmark are from a catalogue at the Geological Survey of Denmark and Greenland, and the other earthquake locations are from a Scandinavian catalogue at Helsinki University. Thick black lines show large postglacial faults $c .9000$ years old, according to Lagerbäck (1991). The curves in central Scandinavia show an early common Scandinavian compilation in project BIFROST of uplift (mm/year). Updated earthquake files for Denmark are available at.geus. $d k$ under seismology, and for the rest of Scandinavia at www.seismo.helsinki.fi. The map is modified from Gregersen \& Voss (2009).

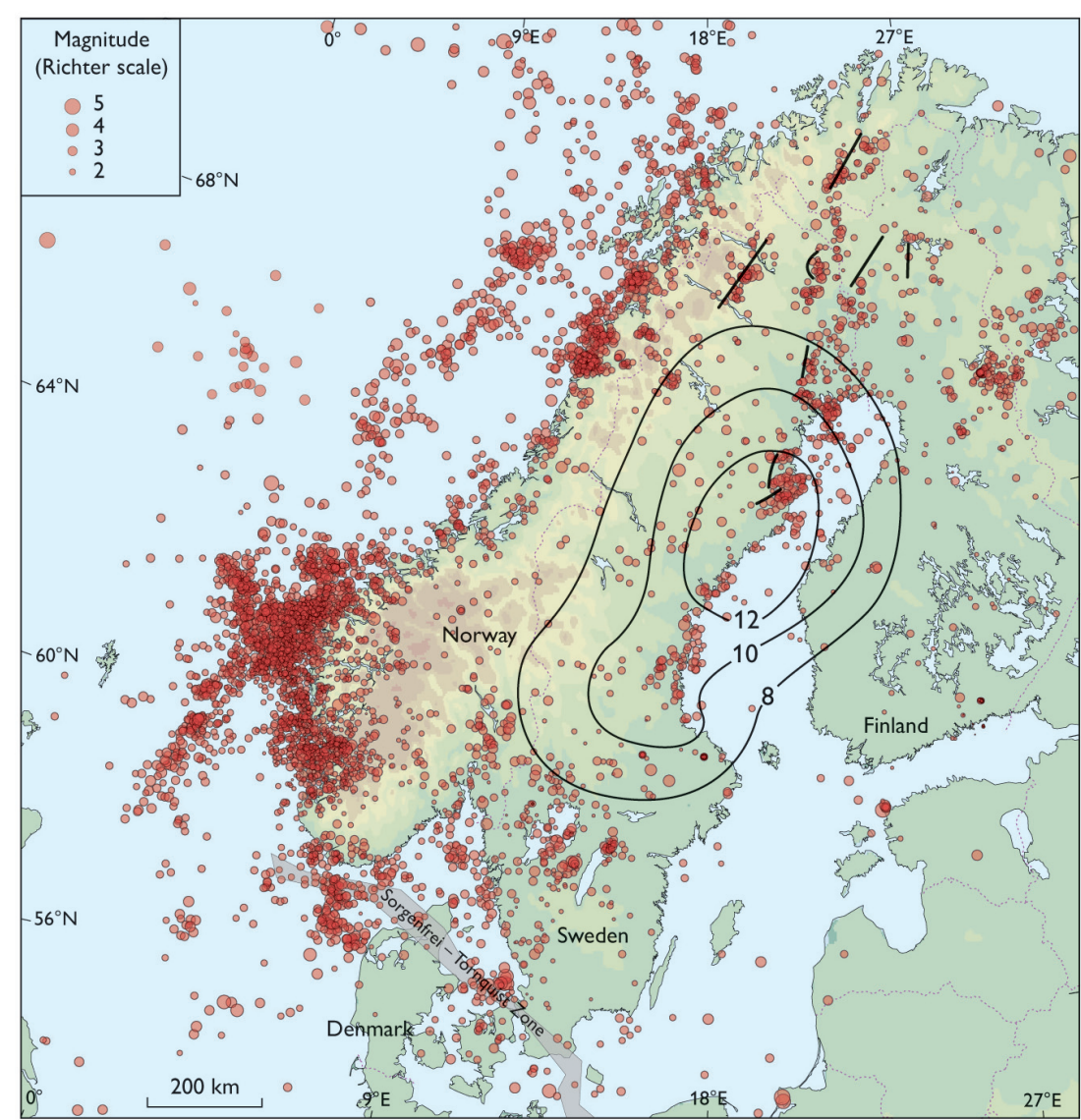


the last hundred years is even lower than that of northern Scandinavia (Fig.1). Historical reports from the past thousand years tell the same story. The stresses in Denmark are fairly homogeneous, mainly influenced by plate motion and only marginally by postglacial uplift, and the earthquake hazard is considered low (Giardini 1999). Here, we assess the longer geological perspective in an attempt to improve long term evaluation of hazard and to demonstrate the need for further geological investigations of stresses and strains in a time scale of several thousands of years. The area discussed is shown in Fig. 2, which also shows generalised, relative sealevel changes after the time of the Littorina Sea in the midHolocene (Christensen 2001).

\section{Discussion of selected areas}

Carlsberg fault, Copenhagen - This fault is one of the most significant faults in the Copenhagen area (Rosenkrantz 1937; Nielsen \& Thybo 2004), and it has been very important for the Carlsberg brewery because large quantities of water could be extracted from the fault zone for brewing beer. Along the fault zone, cracks in house walls are observed, but it is an open question whether it is worse than in the adjacent area (Ovesen et al. 2002; O.W. Christensen, personal communication 1990s; B. Larsen, personal communication 2009; L. Nielsen, personal communication 2009). No earthquakes have been recorded near the fault. A more quantitative area mapping around the fault is needed.

Misfits in the Danish geodetic system have been ascribed to the Carlsberg fault. The base line of the distance measuring system on the island of Amager near Copenhagen has

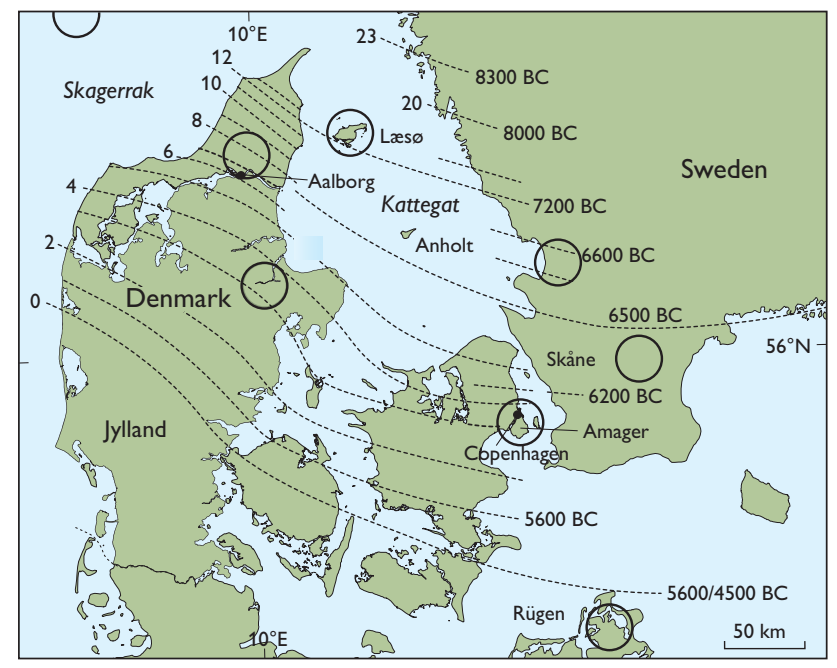

Fig. 2. Map of south-western Scandinavia, showing maximum elevations (m) and ages of shorelines from the Littorina Sea, according to Christensen (2001). The circles show areas discussed in the text. been described as deformed (Ovesen et al. 2002). However, a more probable explanation of this so-called deformation is movements of near-surface sediments at one of the end points of the base line before 1911 due to winter freezing and thawing (M. Aarestrup, personal communication 1991; K. Engsager, personal communication 2009). We consider it unlikely that deformation occurred in 1930 as suggsted by Rosenkrantz (1937) since no movements were registered between 1911 and 1933.

Another base line on Amager (in Danish called 'prøvebane', trial distance) has been reported as deformed (Ovesen et al. 2002). In this case the geodetic problem was identified from observations which showed that there were problems with the end point as mentioned above. One of the ends is sloping strangely, and it must have been disturbed by winter freezing and thawing (K. Engsager, personal communication 2009). We conclude that the Carlsberg fault is not active at present.

Lasø - Indications of a large fault with a displacement of $4 \mathrm{~m}$ have been reported from geological investigations of sand deposits younger than 7000 years on the island of Læsø in Kattegat (Hansen 1977, 1980, 1994). No other sedimentary indications of earthquakes have been identified. Hansen suggested that Læsø does not fit into the post-glacial uplift pattern of the neighbouring coasts of Kattegat, but according to Christensen (2001) the elevations of the highest Littorina Sea shorelines on Læsø fit well into the regional pattern for Kattegat (Fig. 2).

A number of transgressions and regressions occurred over a period of several thousand years in the mid-Holocene in the Kattegat region (Christensen 2001). The last of these so-called Littorina transgressions ended around 4500 years ago. The structural differences in the Sorgenfrei-Tornquist Zone tell about an older geological regime, not the present intraplate inactivity.

Hansen (1980) presented a curve showing changes of tilt of a succession of shorelines based on shoreline elevation measurements without any evaluation of uncertainties. Each point in Fig. 3 represents an average of 10-15 individual measurements that span an elevation of $c .1 \mathrm{~m}$. This $1 \mathrm{~m}$ can be taken as a rough estimate of four times the standard error. If an estimated standard error of $0.25 \mathrm{~m}$ is taken into account, the argument for variations in tilting becomes nonsignificant. We find that the observed differences and the standard errors are of the same magnitude (Fig. 3). The zigzag line of Hansen (1980) goes through the average values of the slopes and the data may as well be explained by a straight line, i.e. within the belt of intervals determined by averages \pm one standard error. Hence we conclude that the differences 
Fig. 3. Tilt of shorelines on Læsø (Hansen 1980, fig. 5) with our estimated standard errors added. Shorelines (dots) are plotted on the horizontal axis, with the youngest to the right. When the standard errors are included it appears that jumps in tilt values are not significant. The data can be interpreted as a steady change of tilt, approximated by the thick sloping line in the diagram, which is generally within one standard error and certainly within two standard errors.

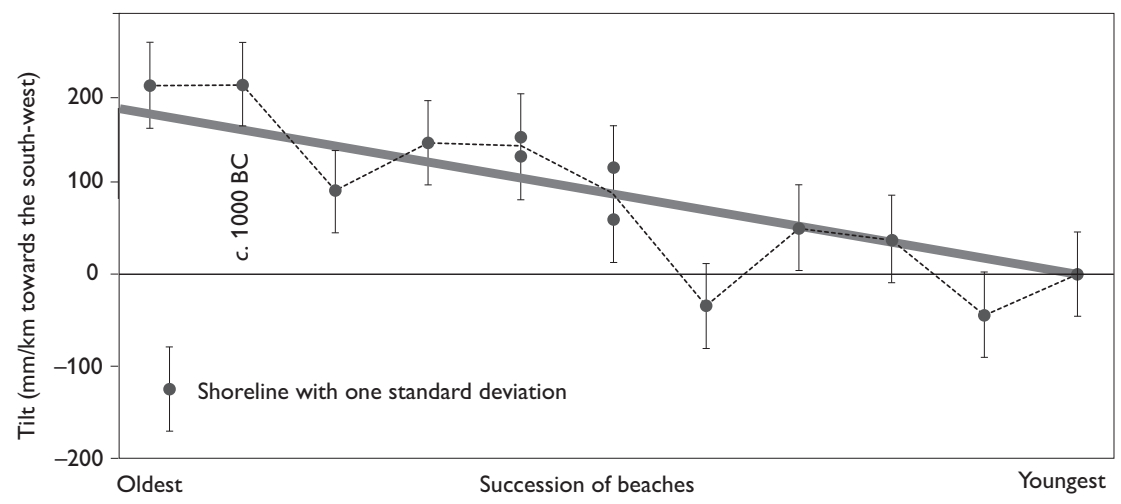

in average tilt cannot be used as an argument for discontinuous and occasionally reverse tilting. The data may as well agree with steady uplift and tilting. The same magnitude of standard errors in the use of geological markers for tilt measurements, and for elevation measurements with respect to sea level, is used in a recent work on Anholt, also in the Kattegat. When changes in sea currents and stormy weather which can influence the development of shorelines are added, the observations on shoreline tilting (Fig. 3) cannot be used on their own as an argument for tectonic tilting.

On the basis of our assessment of old and new arguments we conclude that the bedrock subsurface below Læsø has been uplifted by the same amount as the rest of the Kattegat region, regularly or with minor irregularities. This means that there was no Læsø earthquake $4000-5000$ years ago. The lower-lying parts of Læsø with many well-documented beach ridges have their own exciting history (Hansen $e t$ al. 2011), best explained by regular postglacial uplift together with coastal development influenced by sea currents, climate and weather. One hundred kilometres south-east of Læsø, in the Kattegat Sea, where earthquakes have been registered (Fig. 1), neotectonic small-scale faulting has been recognised (Jensen et al. 2002).

Northern Jylland - It has been suggested that a bend in the geodetic and geological uplift pattern north of Aalborg may reflect a fault (Lykke-Andersen \& Borre 2000). However, according to follow-up measurements the bend could also be due to gradual creep with no indications of earthquakes (Gregersen \& Schmidt 2001).

Central Jylland - Conspicuous so-called fracture valleys in central Jylland were recently discussed by Jakobsen \& Pedersen (2009). The valleys may be related to a deep fault zone, but no evidence exists for present-day earthquakes in this region.

West coast of Sweden - Several localities on the west coast of Sweden have been discussed by Mörner $(2003,2009)$. Signs of geological movements at these localities include variations in postglacial uplift of shorelines, faulting and rock deformation in a few cases, and in many incidences rock slides. Also signs of liquefaction were found at several stratigraphic levels. We encourage a geological and geophysical assessment of these localities.

Skaine - In Skåne in southern Sweden repeated GPS measurements have indicated differential movements of the two sides of the Sorgenfrei-Tornquist Zone. However, these measurements are not considered statistically significant by Swedish geodesists.

Skagerrak - In Skagerrak and southern Norway more earthquake activity takes place than in Denmark (Fig. 1). An assessment similar to the present one has been carried out by Olesen et al. 2004.

Rügen - The bending phenomenon mentioned above is not confined to northern Jylland. Similar geodetic observations were reported from the island of Rügen in northern Germany (Fig. 2; R. Dietrich, personal communication 2008). However, seismological investigations show that northernmost Germany is an earthquake-free region like southernmost Denmark.

\section{Discussion and conclusions}

We have evaluated and discussed a number of reports on geological or geodetic indications of earthquake activity in Denmark. We found no signs of geologically recent faulting or recent crustal deformation. This corroborates that Denmark and its neighbouring areas are characterised by a small earthquake potential. The largest earthquakes recorded had a magnitude of just below 6 on the Richter scale. This is supported by the decrease of uplift stress after the last deglaciation. We conclude that earthquake hazard evaluations in Denmark in the foreseeable future are best based on seismological data 
alone (Gregersen \& Voss 2009). The earthquake zones are those found by historical and instrumental seismological investigations in the seas around Denmark (Fig. 1). Unfortunately this does not mean that destructive earthquakes cannot happen. The situation in Denmark is parallel to that of other intraplate regions. A totally unexpected destructive earthquake happens once every decade somewhere on Earth within a quiet lithospheric plate. Geodynamic stresses exist, which are occasionally released in structurally weak zones. Based on our present state of knowledge of seismology, geodesy and geology, we cannot foresee in which fault zone or region an earthquake may happen in Denmark, but no region is directly earthquake prone. Not even the very significant Sorgenfrei-Tornquist Zone is an earthquake zone (Gregersen et al. 2011).

\section{Acknowledgments}

We appreciate many good discussions with our colleagues Jens Morten Hansen, Peter Johannesen, Lars Henrik Nielsen, Tine B. Larsen, Tanni J. Abramovitz, Abbas Khan, Karsten Engsager, Holger Lykke-Andersen, Torben Bidstrup, Birger Larsen, Jørgen Leth, Lars Nielsen, Henrik Olsen, Hans Thybo and Lars B. Clemmensen.

\section{References}

Christensen, C. 2001: Kystbosættelse og havniveauændringer i stenalderen. In: Jensen, O.L., Sørensen, S.A. \& Hansen, K.M. (eds): Danmarks jægerstenalder - status og perspektiver, 183-193. Hørsholm: Hørsholm Egns Museum.

Giardini, D. (ed.) 1999: The global seismic hazard assessment program (GSHAP) 1992-1999. Annali di Geofisica 42, 280 pp.

Gregersen, S. \& Schmidt, K. 2001: Tektonik i Danmark. Sorgenfrei-Tornquist Zonen. Geologisk Nyt 1, 16-17. Aarhus: Aarhus Universitet.

Gregersen, S. \& Voss, P. 2009: Stress change over short geological time: the case of Scandinavia over 9,000 years since the Ice Age. In: Reicherter, K., Michetti, A.M. \& Silva Barroso, P.G. (eds): Palaeoseismology: historical and prehistorical records of earthquake ground effects for seismic hazard assessment. Geological Society Special Publications (London) 316, 173-178.

Gregersen S. \& Voss, P. 2010: Irregularities in Scandinavian postglacial uplift/subsidence in time scales tens, hundreds, thousands of years. Journal of Geodynamics 50, 27-31.
Gregersen, S., Larsen, T.B. \& Voss, P. 2011: Jordskælv i Sorgenfrei-Tornquist Zonen? Geoviden 1, 18-19. København: Geocenter Danmark.

Hansen, J.M. 1977: Sedimentary history of the island Læsø, Denmark. Bulletin of the Geological Society of Denmark 26, 217-236.

Hansen, J.M. 1980: Læsøs postglaciale udvikling i relation til den Fennoskandiske randzone. Dansk Geologisk Forening, Årsskrift for 1979, 23-30.

Hansen, J.M. 1994: Læsøs tilblivelse og landskaber - om øen der rokker og hopper, 55 pp. København: Danmarks Geologiske Undersøgelse.

Hansen, J.M., Aagaard, T. \& Binderup, M. 2011: Absolute sea levels and isostatic changes of the eastern North Sea to central Baltic region during the last 900 years. Boreas 41, 180-208.

Jakobsen, P.R. \& Pedersen S.A.S. 2009: Fracture valleys in central Jylland - a neotectonic feature. Geological Survey of Denmark and Greenland Bulletin 17,33-36.

Jensen, J.B., Petersen, K.S., Konradi, P., Kuijpers, A., Bennike, O., Lemke, W. \& Endler, R. 2002: Neotectonics, sea-level changes and biological evolution in the Fennoscandian Border Zone of the southern Kattegat Sea. Boreas 31, 133-150.

Khan, S., Knudsen, P. \& Tscherning, C. 2005: Crustal deformations at permanent GPS sites in Denmark. In: Sansò, F. (ed.): A Window on the future of geodesy. Proceedings of the International Association of Geodesy Symposia 128, 556-560.

Lagerbäck, R. 1991: Seismically deformed sediments in the Lansjärv area, northern Sweden. SKB Technical Report 91-17, 58 pp. Stockholm: Svensk Kärnbränslehandtering AB.

Lykke-Andersen, H. \& Borre, K. 2000: Aktiv tektonik i Danmark: der er liv i Sorgenfrei-Tornquist Zonen. Geologisk Nyt 6, 12-13. Aarhus: Aarhus Universitet.

Mörner, N.-A. 2003: Paleoseismicity of Sweden, a novel paradigm, 320 pp. Stockholm: University of Stockholm.

Mörner, N.-A. 2009: Late Holocene earthquake geology in Sweden. In: Reicherter, K., Michetti, A.M. \& Silva Barroso, P.G. (eds): Palaeoseismology: historical and prehistorical records of earthquake ground effects for seismic hazard assessment. Geological Society of Special Publications (London) 316, 179-188.

Nielsen, L. \& Thybo, H. 2004: Location of the Carlsberg Fault zone from seismic controlled-source fan recordings. Geophysical Research Letters 31, L07621, http://dx.doi.org/10.1029/2004GL019603

Olesen, O., Blikra, L.H., Braathen, A., Dehls, J.F., Olsen, L., Rise, L., Roberts, D., Riis, F., Faleide, J.I. \& Anda, E. 2004: Neotectonic deformation in Norway and its implications: a review. Norwegian Journal of Geology 84, 3-34.

Ovesen, N.K., Blem, H., Gregersen, S., Møller, H.M.F. \& Frederiksen, J.K. 2002: Recent terrain-movements in Copenhagen. Dansk Geoteknisk Forenings Bulletin 19, 183-192.

Rosenkrantz, A. 1937: Bemærkninger om det østsjællandske Daniens stratigrafi og tektonik. Meddelelse fra Dansk Geologisk Forening 9, 199-212. 